\title{
A REVIEW ON THE LINK BETWEEN NONFARM EMPLOYMENT, LAND AND RURAL LIVELIHOODS IN DEVELOPING COUNTRIES AND VIETNAM
}

\author{
Tran Quang Tuyen* \\ Faculty of Political Economy, University of Economics and Business, Vietnam National University, \\ Hanoi, Vietnam
}

\begin{abstract}
This paper has reviewed recent empirical evidence on the link between nonfarm employment, land and rural livelihoods in the context of increasing a land loss to urbanization and industrialization in some developing countries and Vietnam. It was found that while land is of great importance to a number of countries, it seems to be less important to others. Land shortage can be a positive factor encouraging rural households' participation in nonfarm activities and improving their welfare in countries in which non-farm job opportunities are available to a large part of the population. Nevertheless, this can negatively affect rural household livelihoods in countries lacking such nonfarm jobs. In Vietnam, nonfarm employment has gained increasing importance to rural livelihoods. In addition, in peri-urban areas where more and more farmland has been lost to rapid urbanization and industrialization, nonfarm employment was found to help households reduce their dependence on farmland and improve their welfare.
\end{abstract}

Keywords: rural livelihoods, nonfarm activities, land loss, land shortage and livelihood diversification

JEL Classification: Q15, Q19

\section{INTRODUCTION}

In many developing countries, where most people mainly depend on agricultural production, land becomes the vital livelihood asset. In almost poor countries, agricultural production plays a crucial role in their growth, employment and livelihoods (Department for International Development (DFID), 2002a). Thus, the link between land and rural

\footnotetext{
*Correspondence to: T. Q. Tuyen, Faculty of Political Economy, University of Economics and Business, Vietnam National University, Hanoi, Vietnam; e-mail: tuyentq@vnu.edu.vn
}

livelihoods has been a topic of interest for researchers and development practitioners. As noted by Deininger and Feder $(1999,1)$ : „In agrarian societies land serves as the main means for not only generating livelihood but often also for accumulating wealth and transferring it between generations". Therefore, land continues to play a key role in the livelihood strategies of rural households and land change will have significant impacts on their livelihoods.

In a consultation document regarding the role of land in poverty eradication, DFID (2002a) asserts that land is a basic livelihood asset since it provides shelter 
and food and all other livelihood activities rely on it. The document also states that the contribution of land to sustainable economic growth is through the productivity and efficiency of land use in agriculture, industries and services. Furthermore, this resource helps achieve higher equality by improving the access of the poor to land security and mitigating vulnerability for the poor by securing their rights to land. Moreover, for farmers, land and their investment in it becomes the most valuable unique asset. The ability to use their land in many ways, not only for farming but also for selling or leasing, provides a safety net for those who are unable to cultivate the land themselves (DFID, 2002a).

However, evidence from many developing countries shows an important role of nonfarm activities in the income-generation of rural households (Carletto, Covarrubias, Davis, Krausova, Stamoulis, Winters, et al, 2007) and the role of land has gradually decreased in rural livelihoods and poverty (Rigg, 2006). Other econometric evidence also indicates that while land shortage has a negative effect on rural households in a number of countries, it has driven households into nonfarm participation and therefore leads them to pursue this way of enhancing their welfare in Vietnam and other developing countries (Winters, Davis, Carletto, Covarrubias, Quiñones, Zezza, et $a l$, 2009). When examining the effect of farmland loss (due to urbanization and industrialization) on rural livelihoods, a number of studies found that farmland have different effects on rural livelihoods in different countries. Positive effects have been found in Bangladesh (Toufique \& Turton, 2002) and China (Parish, Zhe \& Li, 1995; Chen, 1998) but negative effects have been reported in India (Fazal, 2000; 2001). In addtion, other studies show mixed impacts of land loss on rural livelihoods in Ghana (Gregory \& Mattingly, 2009) and Vietnam (Tuyen, Lim, Cameron \& Huong, 2014).

To the best of my knowledge, few studies have reviewed the link between land, nonfarm employment and rural livelihoods in developing countries, and no study reviewed this link in Vietnam, given the context of land shrinking due to urbanization and industrialization. Therefore, the main object of this research is to evaluate the role of land and nonfarm activities in rural livelihoods under the context of rising land loss due to urbanization and industrialization in Vietnam and developing countries.

In this research, the importance of land to rural livelihoods is hypothesized to be different between countries and this difference might stem from the difference in nonfarm employment opportunities between countries. In addtion, given the increasing land loss due to urbanisation and industrialzation in Vietnam, nonfarm employment is hypothesized to help households reduce the shock of land loss and improve their welfare.

In this study, the research method includes a systematic literature review of empirical evidence about the relationship between land, nonfarm employment and rural livelihoods in developing countries and Vietnam. This means that the stated hypotheses will be tested by a critical evaluation of empirical studies conducted by various authors who have analyzed this relationshiBy reviewing recent empirical evidence on this issue in both developing countries and Vietnam, the current paper provides a better understanding of the importance of land and nonfarm activities in rural livelihoods through which useful policy implications can be drawn for Vietnam, given the country's context of farmland shrinking due to rapid urbanization and industrialization.

\section{LAND, NONFARM EMPLOYMENT AND RURAL HOUSEHOLD LIVELIHOODS IN DEVELOPING COUNTRIES}

Due to the importance of land to rural livelihoods, a huge number of studies have investigated the relationship between land and rural livelihoods in developing countries. A large-scale study of many African countries indicated in past decades that urbanization and the underperforming industrial sector growth had been unable to absorb the surplus rural labor available. Meanwhile, the increasing population density in rural areas has led to a rapid decrease in farmland size per household, posing severe challenges to rural livelihoods in this continent 
(Bryceson, 1996). E. Soini (2005) examined the interactions between land use change and livelihoods in the Chaga farming system on the slopes of Mt. Kilimanjaro, Tanzania. They showed that due to an increased population and global climate change, the farm size had declined at an alarming rate, which induced farmers to expand cultivation to the lowlands to support their living. Simultaneously, farmers adapted to new circumstances by intensifying farm production and diversifying their livelihood. Unfortunately, due to a lack of skills and adequate support, not all households were able to equally access attractive nonfarm employment. Additionally, the absence of supportive factors such as credits and markets has considerably restricted farmers from farm production diversification and intensification.

C. M. Shackleton, S. E. Shackleton and B. Cousins (2001) found in South Africa that arable land resource plays a key role in rural livelihoods. Farmers pursued different land-based livelihood strategies such as arable farming and livestock husbandry. The study concluded that income from farm activities is probably greater than the total of other income sources, including transfers from formal employment and state pensions. Furthermore, various studies have pointed out the role of land in rural poverty eradication, and that the small and declining farm size is a severe constraint that the majority of rural households have already confronted in several African Countries (Rigg, 2006). A similar reality can be seen in Central America where households with small landholdings and landless farm workers have become the most vulnerable group among the rural poor (Siegel, 2005).

T. Hanstad, R. Nielsen and J. Brown (2004) applied the rural sustainable livelihood framework to examine the role of land in rural livelihoods in India. They stated that land plays a central role in Indian rural lives. It holds inherent value, and it forms value. A parcel of land can be utilized as a physical or financial asset, and it can be a source of food security and income for a household. In addition, land determines identity and social position within a family and community. Finally, land can also be a basis for political force. For such a strategic role of land in rural livelihoods, the authors proposed some policy implications for securing land rights for the Indian rural poor.
International experience indicates that rapid urbanization and economic growth coincide with the conversion of land from the agricultural sector to industry, infrastructure and residential uses (Ramankutty, Foley \& Olejniczak, 2002). In the context of rapid urbanization in large countries such as China and India, many studies of farmland loss and rural livelihoods can be found in the recent literature. In China, the most populous country, urbanization has been encroaching upon a considerable area of farmland and such encroachment raises special concerns about food security and rural livelihoods (Chen, 2007). Farmland shrinking due to urbanization has significantly affected the livelihoods of rural dwellers. M. Tan, X. Li, H. Xie and C. Lu (2005) indicated that from 1987 to 2000, an area of cultivated land equivalent to around 10 million hectares was converted for urban development or devastated by natural disasters and about 74 percent of total urban land was converted from arable land in the country. Every year, this process caused 1.5 million farmers who lived in the populous suburban areas to lose their cultivated land. D. Tsering, H. C. Bjonness and H. Guo (2007) examined the relationship between farmland conservation and the livelihoods of urban farmers in the Tibet autonomous region of China. Their study found that the arable resource is the most important asset because of its scarcity and this valuable resource was declining on a large scale in this area. They also concluded that land was actually essential for the food security of households and local sustainable development in the future. However, the authors noted that for achieving better livelihood outcomes in the future, farmers should be well-educated and wellequipped with labor skills to mitigate their livelihood dependence on farmland.

Indian rural household livelihoods have also faced the challenge of farmland loss on a large scale. Between 1955 and 1985, approximately 1.5 million hectares of farmland were converted for urban sprawl in India (Fazal, 2000). This process resulted in huge impacts on rural livelihoods. The scenario seems to be more severe in India because its large population places great pressure on food supply. To cope with this hardship, technological advances are likely to push up agricultural productivity. Such an increase, however, 
may be offset by cropland shrinking and the increasing population in this country. In addition, due to the decline in agricultural land, job generation for rural labor is a great challenge for the country, with around 67 percent of its total workforce engaging themselves in the agriculture sector and about two-thirds of the total population living in rural areas (Fazal, 2001).

Using secondary data gathered from various published documents in India, S. Mahapatra (2007) examined how landlessness affected livelihood choices in rural Orrisa, India. The study revealed that about one-third of landless households adopted a livelihood strategy which absolutely relied on wage employment. Due to not having sufficient land for cultivation, many rural laborers were compelled to sell their labor. This sometimes can put them at a disadvantage because of fluctuations in the labor market. Furthermore, the decline in available arable land lowered households' consumption and income in this rural area. Not only influencing livelihood outcomes and strategies, landlessness has also become the main cause of social conflicts which significantly affect the vulnerability context in Indian rural areas (Mahapatra, 2007). Accordingly, the most recent conflicts in India stemmed from land and jobs. The Indian northeast area is a typical case of land shortage causing ethnic conflicts (Fernandes, 2011). Such conflicts are an inevitable consequence of land deficiency and lack of job opportunities which have also been witnessed in other areas such as Rwanda etc. (Ohlsson, 2000).

Because of the importance of land to rural livelihoods, many nations have carried out agrarian policy reforms in order to improve rural livelihoods. Such reforms often focus on land distribution and ensuring farmers' land ownership (Bokermann, 1975; Bradstock, 2006). Agrarian reform programs notably succeeded in Japan and South Korea, parts of West Asia (DFID, 2002a) and in Egypt (DFID, 2002b). In Japan, South Korea and Taiwan, land reforms were extremely successfully implemented by securing private ownership of land for small farmers (Keliang \& Prosterman, 2007). Land policy reforms have also been implemented in several developing countries such as South Africa (Bradstock, 2006), and other Latin American countries (DFID, 2002a).
On the other hand, there are arguments that in certain situations, the rising landless level or land shrinking should be seen as a positive trend because this creates opportunities for diversifying livelihood strategies and mitigating dependence on farmland (e.g. Davis, 2006; Deshingkar, 2005; Koczberski \& Curry, 2005; Rigg, 2006). Ellis (1998) distinguished pull-and-push factors that determine rural livelihood diversification. Land scarcity was categorized as one of the push factors which induces rural households to diversify their livelihood in response to the adverse livelihood contexts. G. Koczberski and G. Curry (2005) investigated the relationship between farmland size decline and change in livelihood strategies among oil palm settlers in Papua New Guinea. Their findings indicated such settlers successfully responded to the farmland shrinking by adopting nonfarm livelihood strategies and intensifying farm production. A similar finding could be found in a study by $\mathrm{H}$. Jansen, J. Pender, A. Damon, W. Wielemaker and R. Schipper (2006), who utilised econometric methods for investigating the determinants of livelihood strategies and outcomes of households in the hillside areas of Honduras. Their findings revealed that land is not the key constraint prohibiting the potential for higher incomes, and more land does not lead to higher per capita income of households. Households possessing less land tend to gain higher productivity or to engage in nonfarm activities. Other econometric evidence in several developing countries provided by Winters et al. (2009) also showed that land-limited households are driven into agricultural and non-agricultural wage activities and thus households are encouraged to follow, on average, this way to raise household welfare. The authors, therefore, confirm the important role of rural nonfarm activities in the livelihood strategies of rural households. The above discussion implies that landlessness or land shortage could be regarded as a positive determinant of rural livelihood diversification.

In developing countries, land in peri-urban areas is in great demand for several purposes, from the construction of the public infrastructure, factories, commercial centers to housing. These demands can result in significant changes in peri-urban livelihoods, for the better or the worse (Mattingly, 2009). As noted by P. Gregory and M. Mattingly (2009), on the 
one hand, urbanization causes intense competition for land, deterioration and a loss of access to natural resources, and these in turn have a negative impact on natural resource-based livelihoods. On the other hand, urbanization brings about a wide range of job opportunities, a better transport availability to markets, an expansion of services and trade, and a competitive advantage of proximity for agricultural products. These factors can allow peri-urban households to diversify their livelihoods and reduce their livelihood dependence on natural resources (Gregory \& Mattingly, 2009). In China, a large share of high value farm production was made in urban and peri-urban areas (Xie, Mei, Guangjin \& Xuerong, 2005). Furthermore, farmland shrinking due to urbanization is often accompanied by economic space expansion to rural areas, offering farmers wide choices of nonfarm employment. A rapid expansion of township and village enterprise development resulted in new nonfarm livelihood opportunities for Chinese farmers (Chen, 1998; Parish, Zhe, \& Li, 1995). It was estimated that nearly 100 million new jobs were created by township and village enterprises in China between 1985 and 2002 (Johnson, 2002). A study in Bangladesh showed that despite a vast amount of farmland being converted for urban expansion, a wide portfolio of new nonfarm employment was created for farmers. Many landless farmers are likely to pursue nonfarm livelihood strategies and for the time being, human capital such as skills and education are emerging as crucial livelihood assets to take advantage of new job opportunities (Toufique \& Turton, 2002).

J. Rigg (2006) reviewed the links between land, farming, poverty and livelihoods in the rural areas of southern countries. Using the evidence from several studies in Asian and African countries, the author demonstrated that livelihoods and poverty have become less related to land while remittances play an increasing role in livelihood outcomes, and that rural livelihoods are diversifying. His main argument is that nonfarm activities are rapidly emerging as the crucial components of rural livelihoods in many developing countries. The Deagrarianization and Rural Employment (DARE) research program conducted in six African countries (Ethiopia, Nigeria, Tanzania, Malawi, Zimbabwe and South Africa) in the 1996-1998 period revealed that non-farm income contributed from $60-80 \%$ of the total household income in these countries (Bryceson, 2002) ${ }^{1}$. Especially in some African and Southeast Asian countries, farmers abandoned their farmland to take up more lucrative nonfarm employment in urban areas (Benayas, Martins, Nicolau \& Schulz, 2007; Ellis, 2000; Kabeer \& Tran, 2000; Kato, 1994). Therefore, this suggests that land has lost its crucial role in shaping rural livelihood and its role has gradually been replaced by other factors such as education, skills, and networks. This also implies that land distribution policy should not be regarded as the main approach to rural poverty eradication.

\section{LAND, NONFARM EMPLOYMENT AND RURAL LIVELIHOODS IN VIETNAM}

In Vietnam, land reform and the process of decollectivization have been performed as part of the economic renovation policies (Đổi Mới) of the country (Kirk \& Nguyen, 2009). Since the Land Law that was enacted in 1993, farmers' long-term and stable use of agricultural land has been secured and this law was implemented by granting land titles (or LandUse Certificates (LUC)) to all households. Together with land reform, the liberalization of agricultural markets was also implemented. In part, such policies stimulated the intensification of rice cultivation, and diversification into new and high value crops such as coffee, which resulted in a considerable improvement in rural household incomes, food security and nutritional state, partially due to increases in rice production (Kirk \& Nguyen, 2009).

The land reform actively stimulates buying, selling and renting activities in the land market and thereby agricultural land can be transferred to and accumulated by more efficient farmers. It may, however, result in a rise of the landless class because some poor rural households may be forced to sell their land in times of urgency (Kirk \& Nguyen, 2009). This phenomenon has led to a number of censures that the land reform has worsened enduring poverty by increasing the number of landless rural households (Ravallion \& Van de Walle, 2008). Nevertheless, using the household panel data from various Vietnam Household Living 
Standard Surveys (VHLSS), M. Ravallion and D. Van de Walle (2008) provided econometric evidence to reject the hypothesis that, in general, increasing landlessness has led to an increase in poverty in rural Vietnam. In addition, the authors found that the rates of poverty reduction among the landless are the same as (or even greater than) those with land. Therefore, they suggest that the rise in the number of landless rural households has been a positive factor in the process of overall poverty alleviation, as farm households have seized new job opportunities, especially paid jobs.

The relationship between land and rural livelihood has been mentioned in some studies of the role of rural nonfarm activities in Vietnam's poverty reduction (for example, Pham, Bui \& Dao, 2010; Van de Walle \& Cratty, 2004). Both these studies provided econometric evidence of the negative effect of farmland on participation in nonfarm activities, meaning that households with more farmland tend to less actively engage in nonfarm activities. D. Van de Walle and D. Cratty (2004) found that although access to land tends to considerably increase household wellbeing, the probability of falling into poverty is substantially higher among households who do not participate in nonfarm self-employment activities. The authors indicate that there is a relationship between diversification out of agriculture and poverty reduction, which could lead to a substantial expectation that the emerging nonfarm sector will be a motive power for rural poverty alleviation. Thus, a policy implication here is that promoting rural nonfarm activities, together with a support for improving the access of the poor to these, are important factors in rural poverty alleviation in Vietnam.

In the context of the rising loss of agricultural land due to urbanization and industrialization in many peripheries of large cities, Vietnamese researchers have attempted to seek an answer to how farmland loss has affected rural household livelihoods, mostly using either qualitative or descriptive statistical methods. Using the secondary data gathered from various published documents in Vietnam, V. C. Nguyen, T. McGrath and W. Pamela (2006) indicated that over the previous decades, Vietnam had experienced rapid urbanization and industrialization in peri-urban areas. One outcome of this process was that a large number of rural households had lost their farmland for the development of industrial zones and urban areas, and many among them had fallen into poverty. However, some case studies in peri-urban areas of Ho Chi Minh City and Hanoi reveal mixed impacts of farmland acquisition on the livelihoods of local people. When investigating a case study in a peri-urban village of Hanoi, where two-thirds of the agricultural land was lost due to urbanization between 1998 and 2007, V. S. Nguyen (2009) found that many households have benefited from their proximity to universities and urban centers. Income from renting out boarding houses to students and migrant workers has emerged as the most important income source for the majority of households. However, a number of other households faced insecure livelihoods because they did not have rooms for renting out and many landless farmers became jobless, particularly elderly and less well-educated farmers. Another case study in a village of Hanoi by T. N. Do (2006) showed that the farmland loss caused a loss of arable land, food supply and agricultural income sources. Many land-losing households actively adapted to the new circumstance by diversifying their labor in manual labor jobs. Consequently, a high but unstable income from casual wage work became the main income source for many households. In the case of a peri-urban commune in Ho Chi Minh City, where most agrarian land was taken for non-agricultural land uses such as industrial zones or the residential land, N. T. Vo (2006) found that farmers there actively switched from rice cultivation to animal husbandry and horticulture. Moreover, nonfarm job opportunities also increased with rapid urbanization and industrialization, making young rural workers less interested in agricultural jobs.

In a study conducted by Q. V. Nguyen, H. M. Nguyen, X. M. Nguyen, Q. H. Pham, and V. T. Nguyen (2005), the mixed effects of the farmland loss on local rural households were also mentioned. While a number of land-losing farmers who resided close to newlyurbanized areas earned higher cash income than for farm work; other land-losing farmers, particularly those with the low levels of education, became jobless and impoverished. Some evidence based on survey results also indicates that a farmland loss exerts different effects on households. It was 
estimated that about two-thirds of the land-losing households benefited from higher job opportunities and an upgraded infrastructure; for the rest, the land loss resulted in a serious economic interruption, particularly if all productive land was acquired, or family members did not attain suitable education or vocational skills to switch to new jobs (Asian Development Bank (ADB), 2007). Moreover, the results from a large-scale survey in eight developed cities and provinces with the highest level of farmland loss, provides quite a detailed picture of both positive and negative effects of farmland loss on household livelihood outcomes. On average, while about half of the land-losing households reported suffering from a significant decline in farm income, almost half among them earned a higher income from other nonfarm sources after losing their land. Regarding the total income that households earned after farmland loss, 25 percent of the land-losing households obtained a higher level, while 44.5 percent maintained the same level and 30.5 percent experienced a decline (Le, 2007).

T. D. Nguyen, D. T. Vu and L. Philippe (2011) investigated livelihood adaptation and social differentiation among land-losing households in some communes of Hung Yen, a neighboring province of Hanoi, where the farmland of communes in the study declined by 70 percent due to farmland conversion for industrial zones and clusters in the 2001-2006 period. They found that diversification in both farm and nonfarm activities emerged as the most common livelihood strategy among land-losing households. It was followed by a livelihood strategy based on nonfarm paid work and self-employment, and finally by an agricultural intensification strategy. Despite the low return from agriculture and more opportunities for lucrative nonfarm jobs, the households maintained farming activities not only for their basic and secure livelihood but also for the cultural identity. In addition, among the land-losing households, those with a farming background tend to be at a disadvantage in taking up high-return activities. Finally, the difference in returns with different livelihood strategies was one of the main causes of increasing social stratification.

Using a quantitative livelihood approach to investigate the impact of farmland loss (due to urbanization) on household livelihoods in Hanoi's peri-urban areas, a study (Tuyen et al, 2014) provided an important econometric piece of evidence that while farmland loss has a negative effect on the farm income source of households, it exerts a positive impact on the nonfarm participation of households, notably manual labor jobs in Hanoi's peri-urban areas. Such low-skilled jobs are relatively easily accessible to many land-losing households, which might allow them to supplement their income shortage due to the loss of farmland. This study also found that education and the prime location for doing business are important factors that can help households pursue lucrative nonfarm activities. Based on the empirical findings, T. Q. Tuyen et al (2014) suggested that providing land-losing households with a plot of land in a prime location can help them take up nonfarm household businesses such as opening a shop or a workshop or for rental purposes. In addition, encouraging parents' investment in their children's education may be a way to obtain well-paid jobs for the next generation. Finally, improvement in the local infrastructure and setting up new local markets might be an effective way to generate more nonfarm jobs for land-losing farmers, especially elderly landless farmers.

\section{CONCLUSION}

In sum, the topic of the role of land to rural livelihoods remains highly controversial, supporting the first hypothesis that the importance of land to rural livelihoods is very different between countries. In some countries, land is essential for rural livelihoods possibly because of the limited opportunities for farmers to engage in nonfarm activities. In such countries, farming is the only opportunity open to farmers and thus land shrinking severely threatens rural livelihoods. In other countries, land is becoming less important in terms of determining rural livelihood, which is most likely because people there have more chances to participate in nonfarm economic activities. The above discussion implies that land is not an equally important determinant of rural livelihoods in all agrarian countries.

Regarding the relationship between farmland loss (due to urbanization and industrialization) and rural 
livelihoods, the literature review for both Vietnam and other countries indicates that farmland loss has mixed impacts on rural household livelihoods. It is necessary to distinguish the overall influences of farmland loss at the local level and its specific impacts on landlosing households. On the one hand, at the household level, farmland loss functions as a push factor that forces land-losing households to find alternative livelihoods. As a result, farmland loss might be a shock for households whose livelihood largely or entirely depended on farming. On the other hand, at the community level, farmland loss has resulted in the construction of industrial zones, new urban areas and an improved local infrastructure, which in turn has benefited local dwellers by creating a wide range of nonfarm job opportunities. Therefore, farmland loss has both negative and positive effects on local people. This suggests that new lucrative occupations will be available for households with better educational backgrounds or vocational skills, while such opportunities may not be accessible to those with limited endowments of human capital.

The conversion of agricultural to non-agricultural land uses for urbanization and industrialization is an almost inevitable tendency during the phases of economic development and population growth (Tan, Beckmann, Van Den Berg \& Qu, 2009). This implies that in Vietnam, a loss of a huge area of agricultural land will be unavoidable without stopping farmland conversion for industrialization and urbanization. As a result, a large number of farm households might be negatively affected by farmland loss in the near future. The literature review in Vietnam shows that even though farmland has retained an important role in determining household livelihoods in Vietnam's rural areas, nonfarm-based-livelihoods have gained increasing importance. As previously discussed, nonfarm activities have several advantages, especially for land-losing households. Thus, this supports the second hypothesis that nonfarm employment can help land-losing households reduce their dependence on farmland and improve their income in Vietnam. As a result, policy intervention in improving the access of households to lucrative non-farm activities should be of a practical use.
However, it should be noted that the findings of the case of Vietnam might not be true for some developing countries which are not similar in several socioeconomic characteristics. Thus, the policy implications for Vietnam might not be seen as valuable to other developing countries. This suggests that future research should examine this issue in several other developing countries.

\section{ENDNOTE}

1 ,Deagrarianization is defined as a process of: (i) economic activity reorientation (livelihood), (ii) occupational adjustment (work activity), and (iii) spatial realignment of human settlement (residence) away from agrarian patterns" (Bryceson, 1996, 99).

\section{ACKNOWLEDGMENTS}

This paper was carried out as a part of the author's PhD research, which had been undertaken in Department of Economics, University of Waikato, New Zealand and financially supported by the Ministry of Education and Training of the Socialist Republic of Vietnam (Decision No. 3470/ QÐ-BGĐT) and the University of Waikato.

\section{REFERENCES}

Asian Development Bank (ADB). (2007). Agricultural land conversion for industrial and commercial use: Competing interests of the poor. In ADB (Ed.), Markets and Development Bulletin (pp. 85-93). Hanoi, Vietnam.

Benayas, J. M. R., Martins, A., Nicolau, J. M., \& Schulz, J. J. (2007). Abandonment of agricultural land: An overview of drivers and consequences. $C A B$ reviews: Perspectives in agriculture, veterinary science, nutrition and natural resources, 2(57), 1-14.

Bokermann, H. (1975). Land reform in developing countries. Intereconomics, 10(11), 341-343.

Bradstock, A. (2006). Land reform and livelihoods in South Africa's Northern Cape province. Land Use Policy, 23(3), 247259. 
Bryceson, D. F. (1996). Deagrarianization and rural employment in sub-Saharan Africa: A sectoral perspective. World Development, 24(1), 97-111.

Bryceson, D. F. (2002). The scramble in Africa: Reorienting rural livelihoods. World Development, 30(5), 725-739.

Carletto, G., Covarrubias, K., Davis, B., Krausova, M., Stamoulis, K., Winters, P., et al. (2007). Rural income generating activities in developing countries: Re-assessing the evidence. Electronic Journal of Agricultural and Development Economics, 4(1), 146-193.

Chen, J. (2007). Rapid urbanisation in China: A real challenge to soil protection and food security. Catena, 69(1), 1-15.

Chen, W. (1998). The political economy of rural industrialisation in China: Village conglomerates in Shandong Province. Modern China, 24(1), 73-96.

Davis, J. R. (2006). Rural non-farm livelihoods in transition economies: emerging issues and policies. Electronic Journal of Agricultural and Development Economics, 3(2), 180-224.

Deininger, K., \& Feder, G. (1999). Land Institutions and Land Markets. (Policy Research Working Paper). The World Bank. Washington, D.C.

Deshingkar, (2005, March). Maximizing the benefits of internal migration for development. Paper presented at the Regional Conference on Migration and Development in Asia, Lanzhou, China. from www.odi.org.uk/resources/docs/2358. pdf

Department for International Development (DFID) UK. (2002a). Better livelihoods for poor people: The role of land policy. (Consultation document). Department for International Development, UK.

Department for International Development (DFID) UK. (2002b). Better livelihood for poor people: The role of agriculture. (Consultation document). Department for International Development, UK. From webarchive.nationalarchives.gov. uk/+/www.dfid.gov.uk/Pubs/files/agriculture_consult.pdf.

Do, T. N. (2006). Loss of land and farmers' livelihood: A case study in Tho Da village, Kim No commune, Dong Anh district, Hanoi, Vietnam. Unpublished master thesis, Swedish University of Agricultural Sciences, Uppsala, Sweden.

Ellis, F. (1998). Household strategies and rural livelihood diversification. Journal of Development studies, 35(1), 1-38.

Ellis, F. (2000). Rural Livelihoods and Diversity in Developing Countries. New York, NY: Oxford University Press.
Fazal, S. (2000). Urban expansion and loss of agricultural land-a GIS based study of Saharanpur City, India. Environment and Urbanisation, 12(2), 133-149.

Fazal, S. (2001). The need for preserving farmland: A case study from a predominantly agrarian economy (India). Landscape and Urban Planning, 55(1), 1-13.

Fernandes, W. (2011). Land as livelihood vs land as commodity. Inforchageindia. Retrieved from http://infochangeindia.org/ agenda/battles-over-land/land-as-livelihood-vs-land-ascommodity.html

Gregory, P., \& Mattingly, M. (2009). Goodbye to natural resource-based livelihoods? Crossing the rural/urban divide. Local Environment, 14(9), 879-890

Hanstad, T., Nielsen, R., \& Brown, J. (2004). Land and livelihoods: Making land rights real for India's rural poor (LSP Working Paper 12). Food and Agriculture Organisation.

Jansen, H., Pender, J., Damon, A., Wielemaker, W., \& Schipper, R. (2006). Policies for sustainable development in the hillside areas of Honduras: A quantitative livelihoods approach. Agricultural Economics, 34(2), 141-153.

Johnson, G. D. (2002). Can agricultural labour adjustment occur primarily through creation of rural non-farm jobs in China? Urban Studies, 39(12), 2163-2174.

Kabeer, N., \& Tran, T. V. A. (2000). Leaving the rice fields but not the countryside: Gender, livelihood diversification and pro-poor growth in rural Viet Nam. (Occasional Paper 13). Research Institution for Social Development, United Nations.

Kato, T. (1994). The emergence of abandoned paddy fields in Negeri Sembilan, Malaysia. Southeast Asian Studies, 32(2), 145-172.

Keliang, Z., \& Prosterman, R. (2007). Securing Land Rights for Chinese Farmers: A Leap Forward for Stability and Growth. (Development Policy Analysis No. 3). The Cato Institue. Washington, D.C.

Kirk, M., \& Nguyen, D. T. A. (2009). Land-tenure policy reforms: Decollectivization and the Doi Moi system in Vietnam (IFPRI Discussion Paper). International Food Policy Research Institute.

Koczberski, G., \& Curry, G. (2005). Making a living: Land pressures and changing livelihood strategies among oil palm settlers in Papua New Guinea. Agricultural Systems, 85(3), 324-339.

Le, D. (2007). Thu nhập, đời sông, việc làm của người có đất bị thu hồi để xây dựng các khu công nghiệp, khu đô thị, kêt cấu hạ tầng 
kinh tế-xã hội, các công trình công cộng phuc vu lợi ích quốc gia [Income, life and employment of those whose land was acquired for the construction of industrial zones, urban areas, infrastructures and public projects]. Hanoi, Vietnam: National Political Publisher.

Mahapatra, S. (2007). Livelihood pattern of agricultural labour households in rural India. South Asia Research, 27(1), 79-103.

Mattingly, M. (2009). Making land work for the losers: Policy responses to the urbanisation of rural livelihoods. International Development Planning Review, 31(1), 37-53.

Nguyen, T. D., Vu, D. T., \& Philippe, L. (2011, October). Peasant responses to agricultural land conversion and mechanism of rural social differentiation in Hung Yen province, Northern Vietnam. Paper presented at the 7th ASAE International Conference, Hanoi, Vietnam, from http://orbi.ulg.ac.be/ handle/2268/100467

Nguyen, Q. V., Nguyen, H. M., Nguyen, X. M., Pham, Q. H., \& Nguyen, V. T. (2005). The impact of urbanisation on agriculture in Hanoi: Results of inteviews with districts and municipality officals. Hanoi, Vietnam. From http://www.cares.org.vn/webplus/att achments/2976a896b1e0df4268a563125e416350-03.pdf

Nguyen, V. C., McGrath, T., \& Pamela, W. (2006). Agricultural land distribution in Vietnam: Emerging issues and policy implications. MPRA Paper No. 25587.

Nguyen, V. S. (2009). Industrialisation and urbanisation in Vietnam: How appropriation of agricultural land use rights transformed farmers' Livelihoods in a Per-Urban Hanoi Village? (EADN working paper No.38).

Ohlsson, L. (2000). Livelihood conflicts: Linking poverty and environment as causes of conflict. Swedish International Development Cooperation Agency (Sida). Stockholm, Sweden.

Parish, W., Zhe, X., \& Li, F. (1995). Nonfarm work and marketization of the Chinese countryside. The China Quarterly, 143(September), 697-730.

Pham, T. H., Bui, A. T., \& Dao, L. T. (2010). Is nonfarm diversification a way out of poverty for rural households? Evidence from Vietnam in 1993-2006. PMMA Working Paper 2010-17.

Ramankutty, N., Foley, J., \& Olejniczak, N. (2002). People on the land: Changes in global population and croplands during the 20th century. AMBIO: A Journal of the Human Environment, 31(3), 251-257.

Ravallion, M., \& Van de Walle, D. (2008). Does rising landlessness signal success or failure for Vietnam's agrarian transition? Journal of Development Economics, 87(2), 191-209.
Rigg, J. (2006). Land, farming, livelihoods, and poverty: Rethinking the links in the rural South. World Development, 34(1), 180-202.

Shackleton, C. M., Shackleton, S. E., \& Cousins, B. (2001). The role of land-based strategies in rural livelihoods: The contribution of arable production, animal husbandry and natural resource harvesting in communal areas in South Africa. Development Southern Africa, 18(5), 581-604.

Siegel, (2005). Using an asset-based approach to identify drivers of sustainable rural growth and poverty reduction in Central America: A conceptual framework (World Bank Policy Research Working Paper 3475). The World Bank.

Soini, E. (2005). Land use change patterns and livelihood dynamics on the slopes of Mt. Kilimanjaro, Tanzania. Agricultural Systems, 85(3), 306-323.

Tan, M., Li, X., Xie, H., \& Lu, C. (2005). Urban land expansion and arable land loss in China: A case study of BeijingTianjin-Hebei region. Land Use Policy, 22(3), 187-196.

Tan, R., Beckmann, V., Van Den Berg, L., \& Qu, F. (2009). Governing farmland conversion: Comparing China with the Netherlands and Germany. Land Use Policy, 26(4), 961974.

Toufique, K. A., \& Turton, C. (2002). Hand not land: How livelihoods are changing in rural Banladesh. Dhaka, Bangladesh: Bangladesh Institute of Development Studies.

Tsering, D., Bjonness, H. C., \& Guo, H. (2007, September). Land conservation and urban farmers livelihoods: A critical pair in an urban strategy in Gyantse, Tibet autonomous region, P.R. of China. Paper presented at the 43rd ISOCARP Congress 2007, Antwerp, Bengium. Retrieved from http://www.isocarp.net/ Data/case_studies/1034.pdf

Tuyen, T. Q., Lim, S., Cameron, M. P., \& Huong, V. V. (2014). Farmland loss and livelihood outcomes: An econometric analysis of household surveys in Vietnam. Journal of the Asia Pacific Economy, 19(2), 423-444.

Van de Walle, D., \& Cratty, D. (2004). Is the emerging nonfarm market economy the route out of poverty in Vietnam? Economics of Transition, 12(2), 237-274.

Vo, N. T. (2006). Livelihoods of people living in a peri-urban area of Ho Chi Minh City: A case study: Hung Long commune, Binh Chanh district, Ho Chi Minh City, Vietnam (Unpublished master thesis). Swedish University of Agricultural Sciences, Uppsala, Sweden.

Winters, P., Davis, B., Carletto, G., Covarrubias, K., Quiñones, E. J., Zezza, A., et al. (2009). Assets, activities and rural 
income generation: evidence from a multicountry analysis. World Development, 37(9), 1435-1452.

Xie, Y., Mei, Y., Guangjin, T., \& Xuerong, X. (2005). Socio- economic driving forces of arable land conversion: A case study of Wuxian City, China. Global Environmental Change Part A, 15(3), 238-252.

$$
\begin{array}{r}
\text { Received on } 21^{\text {st }} \text { May 2014, } \\
\text { after revision, }
\end{array}
$$

Tran Quang Tuyen, PhD, is a Lecturer in Economics, at the Faculty of Political Economy, University of Economics and Business, Vietnam National University, Hanoi, Vietnam. He received his PhD degree in Economics at the University of Waikato, Hamilton, New Zealand, in 2013. His research interests cover land, livelihoods and household welfare. He has several papers published in SSCI journals, including Applied Economics Letters; Journal of the Asia Pacific Economy; International Development Planning Review, and Hitotsubashi Journal of Economics. 


\title{
ISTRAŽIVANJE POVEZANOSTI NEPOLJOPRIVREDNOG ZAPOŠLJAVANJA, ZEMLJIŠTA I ŽIVOTNIH USLOVA NA SELU U ZEMLJAMA U RAZVOJU I VIJETNAMU
}

\author{
Tran Quang Tuyen \\ Fakultet Političke Ekonomije, Univerzitet Ekonomije i Biznisa, Nacionalni Univerzitet Vietnama, \\ Hanoj, Vijetnam
}

U ovom radu daje se pregled nedavnih empirijskih dokaza o postojanju veze između zapošljavanja izvan poljoprivrede, zemljišta i životnih uslova na selu, u kontekstu sve većeg gubitka zemljišta u nekim zemljama u razvoju i Vijetnamu, usled urbanizacije i industrijalizacije. Došlo se do saznanja da dok je, s jedne strane, zemljište veoma bitno u jednom broju zemalja, s druge strane, postoje zemlje u kojima je ono manje značajno. Nedostatak zemljišta može biti pozitivan faktor koji ohrabruje seoska domaćinstva da učestvuju u nepoljoprivrednim aktivnostima i poboljšava njihovu opštu dobrobit, u zemljama u kojima su velikom delu stanovništva dostupna radna mesta izvan poljoprivrede. Ipak, to može negativno uticati na životne uslove seoskih domaćinstava u zemljama u kojima nema radnih mesta izvan poljoprivrede. $U$ Vijetnamu, zapošljavanje izvan poljoprivrede dobilo je na značaju u odnosu na životne uslove na selu. Pored toga, utvrđeno je da u peri-urbanim oblastima, sa ubrzanim smanjivanjem obradivog zemljišta usled brze urbanizacije i industrijalizacije, zapošljavanje izvan poljoprivrede pomaže domaćinstvima da smanje svoju zavisnost od obradivog zemljišta i poboljšaju svoj životni standard.

Ključne reči: životni uslovi na selu, nepoljoprivredne aktivnosti, gubitak zemlijšta, nedostatak zemljišta i diversifikacija životnih uslova

JEL Classification: Q15, Q19 